\title{
BIRTH AT THE HEALTH CENTER OR AT HOME: AN ANALYSIS OF BIRTHING CARE AMONG THE KUKAMAS KUKAMIRIAS WOMEN OF PERU
}

\author{
Rosário del Socorro Avellaneda Yajahuanca ${ }^{1}$, Claudia Valença Fontenele², \\ Brena Figueiredo Sena ${ }^{3}$, Simone Grilo Diniz ${ }^{4}$
}

\begin{abstract}
Objective: to describe and analyze the culture and traditions related to pregnancy, childbirth and postpartum care of the Kukama kukamiria women, living in the Peruvian Amazon, and their experiences and perceptions of care at home compared to that received at the health center. Methods: a qualitative study based on ethnography that seeks to analyze traditional knowledge and practices of self-care, taking into account descriptions of home births attended by traditional midwives, compared to that of birth care at the health institution. Results: home delivery prioritizes women's' comfort, through the use of teas, baths and specific rituals in caring for the placenta; dietary regulations and attention to environmental aspects such as temperature and lighting are built into care. At the health facilities, routine interventions include acceleration of labor with the use of drugs, vaginal cutting (episiotomy), immobilization in lithotomy position, and the disposal of the placenta as garbage; which is perceived as inadequate and aggressive. Conclusion: a preference for traditional care is justified based on feelings of neglect and vulnerability at institutionalized health centers, resulting from the lack of consideration by the health services for the cultural and well-being specificities of the Kukama Kukamiria women.
\end{abstract}

Key words: indigenous population, maternal health, health services, ethnography.

\section{INTRODUCTION}

The health of mothers and newborns among vulnerable populations has been a matter of priority in public policy globally, including efforts towards the Millennium Development Goals. In Peru, many social policies have been designed to meet the needs of the most vulnerable groups, such as the indigenous people. Among these policies are those that seek to increase women's access to trained professionals within the health system during labor and birth ${ }^{1}$.

Institutional deliveries, ie, within the equipped health system, represent $15 \%$ of total births in rural Peru. Within the region of Loreto, in 2010, health centers cared for 198 mothers in the countryside (this figure does not specify numbers for the indigenous population), while 391 births were attended by traditional midwives ${ }^{2}$.
Generally in Peru, the average number of children per woman is 2,0 . There are no specific numbers of births by indigenous women, however experience with this reality allows us to estimate an average of six to ten children per woman. The fertility rate is higher in the jungle and in the rural areas $s^{3,4}$.

The rural, indigenous and "amazônica" (from the Amazon) woman is the most affected by rural poverty: they have less education, higher rates of illiteracy and maternal mortality ${ }^{5}$. Thus, it is important to analyze the crucial factors influencing this health scenario, and to note the existence of deficiencies and disparities within the region, which lacks the most basic health assistance. These inequities, as well as a deficiency of well-functioning health services - when they exist at all - result in a context where motherhood can become a risk factor for the life of women and newborns.

1 Doctoral Research Associate. Department of Maternal and Child Health, Universidade de São Paulo (FSP/USP), São Paulo, Brasil.

2 Post-doctoral Research Associate. Department of Maternal and Child Health, Universidade de São Paulo (FSP/USP), São Paulo, Brasil.

3 Master's in Public Health MPH. Department of Sociomedical Sciences and Global Health. Columbia Mailman School of Public Health, New York, NY, USA

4 Associate Professor. Department of Maternal and Child Health, Universidade de São Paulo (FSP/USP), São Paulo, Brasil. Corresponding author: ravellaneday@yahoo.es

Suggested citation: Yajahuanca RSA et al. Birth at the health center or at home: an analysis of birthing care among the kukamas kukamirias women of Peru. Journal of Human Growth and Development 2013; 23(3): 322-330

Manuscript submitted dec 28 2012, accepted for publication Jul 202013. 
Among Kukama kukamiria women, pregnancy is followed by a set of ancestral customs that are transmitted from one generation to another, comprising of a series of specific assumptions and attitudes. This reality imposes a need for understanding the role of traditional practices in maternal care ${ }^{6}$.

Although the institutionalization of labor and technological advancements have provided important benefits for maternal and child health, it has also equally led to the incorporation of numerous interventions, some could be considered unnecessary or even harmful7,8. Similarly, this institutionalization has also led to the devaluation of delivery through traditional practices, and the work of midwives as a whole ${ }^{9}$.

The Kukama kukamiria population has a relatively distinct and complex view of health and well-being compared to that of the bio-medical conception. They believe that health depends on the harmonious coexistence of human beings and natural forces, within oneself and among others towards wellness and well-being. Often these conceptions are in conflict with the approaches used by official health services. Such conflicts aid in reducing the potentially positive impact that such services could provide to the health of the population. These conflicts are especially important when we find contexts within Latin America where a "perinatal paradox" exists, ie, when the increased number of services is not found to be proportional to an improvement in health indicators, demanding that the available services become better designed to serve the various health interests of the diverse population it serves ${ }^{8,10}$.

Thus, the goal of this study is to describe the culture and traditions related to pregnancy, childbirth and postpartum care experienced by the Kukama kukamiria women, from the Peruvian Amazon, their experiences within both traditional and institutionalized maternal health care, and their reasons for giving preference towards one or the other system of care.

\section{METHODS}

A qualitative research approach grounded on ethnography, conducted through a descriptive, analytical and exploratory method. 25 individual interviews were conducted with pregnant and postpartum women, midwives, medical herbalists, partners, and health care providers. Participant observation of the services provided was also conducted.

Interviews were given in the region of Loreto, Loreto Province, in the capital city of Iquitos, Peru, among the San Regis community, which has approximately 1,200 residents belonging to the ethnic group Kukama kukamiria. The language spoken in public is Spanish, while in private their native language, Kukama kukamiria.
Loreto is a region of Peru located in the extreme northeastern part of the country. It is characterized mainly by its extensive territory, tropical climate, high population dispersion and multiculturalism. Within this region there are 42 ethno-linguistic groups, with diverse cultural, economic and political characteristics from other populations in Peru ${ }^{11}$.

From this universe, the study focused its investigation on the ethnic community Kukama kukamiria from the San Regis community, by the Marañón River. Organized into numerous groups of families, the Kukama kukamiria exercise for the most part, fishing and hunting activities. From an ethnographic perspective, cultural scenarios, beliefs, experiences, attitudes, thoughts and reflections of women in the community of San Regis were described, taking into account the same terms and meanings that the participants considered to describe their actions.

The experience of following the work of healthcare providers allowed for observation of how care is provided during a medical consultation: medical care for children, prenatal care, as well as care of pregnant women at the eve of birth. Among the women interviewed, most had incomplete basic studies, except for one who described having none. The health care providers interviewed were nurses and nursing technicians with university level and technical education, respectively.

The techniques used to capture the empirical reality were participant observation with added descriptions from field diaries, and interviews. Participant observation was a key strategy in mapping various aspects of the community. This technique allowed for an approximation of the reality narrated by the subjects and the meanings guiding their actions. As stated by Haguette ${ }^{12}$, participant observation represents a process of interaction between the theory and methods used by the researcher in building a knowledge base. During interactions with the residents of the San Regis community, everything was recorded: everyday observations of dialogues, work, as well as regular meetings within the community. Notes were taken at the end of each day, at times with the help of a flashlight.

Later, after a long period of immersion in the community, interviews became supplemented with greater depth, breadth and specificity; all information was gathered from the perspective of the subjects: their worldview, opinions and evaluations, both with regard to deliveries performed at home and at the health center.

Interviews were recorded and transcribed whenever there was consent; daily occurrences especially those related to birthing were recorded through photographs.

Data collection began after approval by the Research Ethics Committee (IRB) of São Paulo's School of Public Health and the Ethics Committee at Peru's National Institute of Health. To preserve 


\section{Map: Ethnolinguistic map of Pery (2007)}

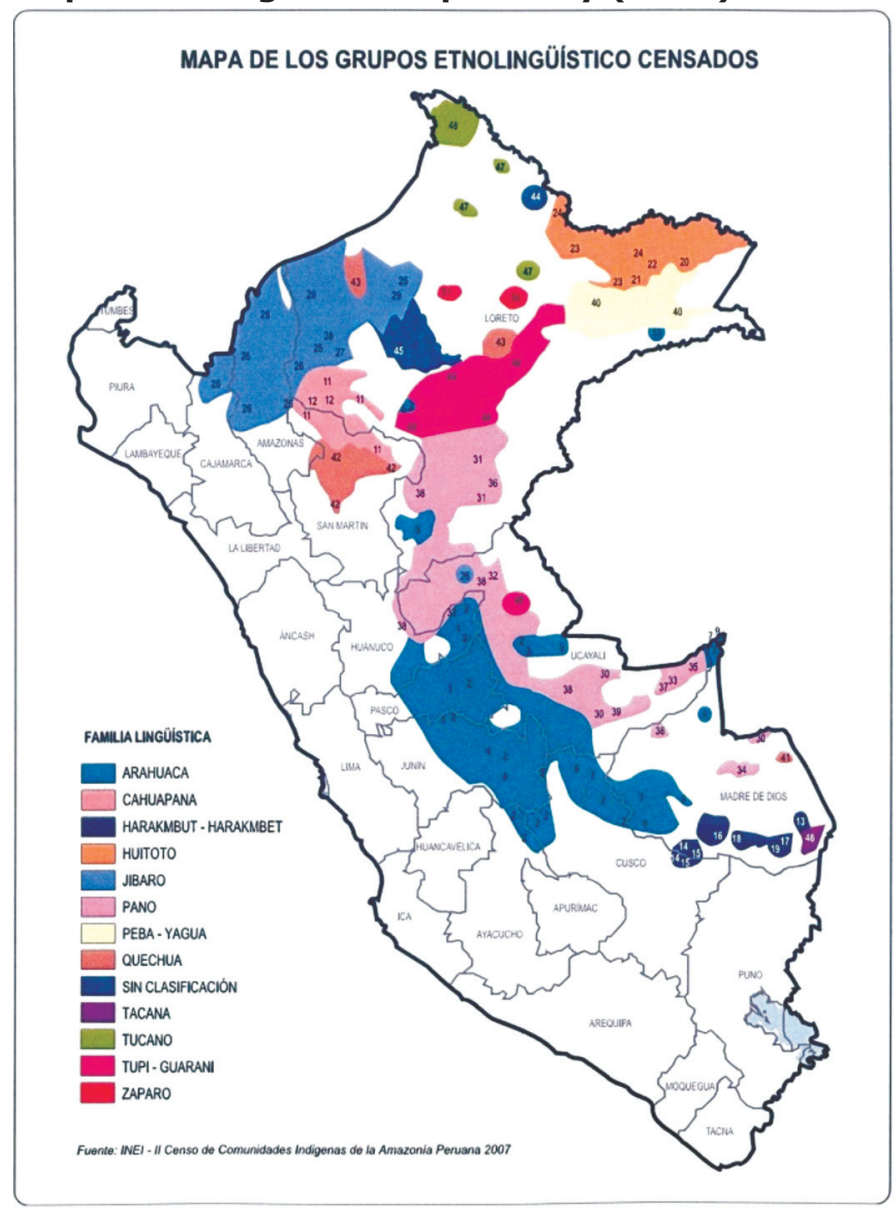

Reference: Instituto Nacional de Estadística e Informática (INEI) 2007. II Censo de comunidades indígenas de la Amazonia Peruana.

the anonymity of participants and health care providers, their real names were replaced by fictitious ones.

Due to greater availability of time, interviews with healthcare providers were more relaxed, performed at night in the health center. On the other hand, interviews with the women were conducted in their own homes.

Each conversation lasted an hour on average, however, interviews with the women usually lasted longer, with a few being interrupted by the need to tend to the farm, cooking or washing.

In the case of longer interview sessions lasting more than an hour, a continuation meeting was scheduled for the following day. Interviews were scheduled according to the availability of the women. On certain occasions, the researcher met interviewees multiple times for completion of the interview. During follow-up meetings it was observed that some women showed more confidence and gave longer, more personal reports, focusing on family issues and other life stories recalled in the moment. Other times women expressed anger towards the violence they recalled experiencing when seeking the health services, and were met with disrespect, mistreatment or disregard.

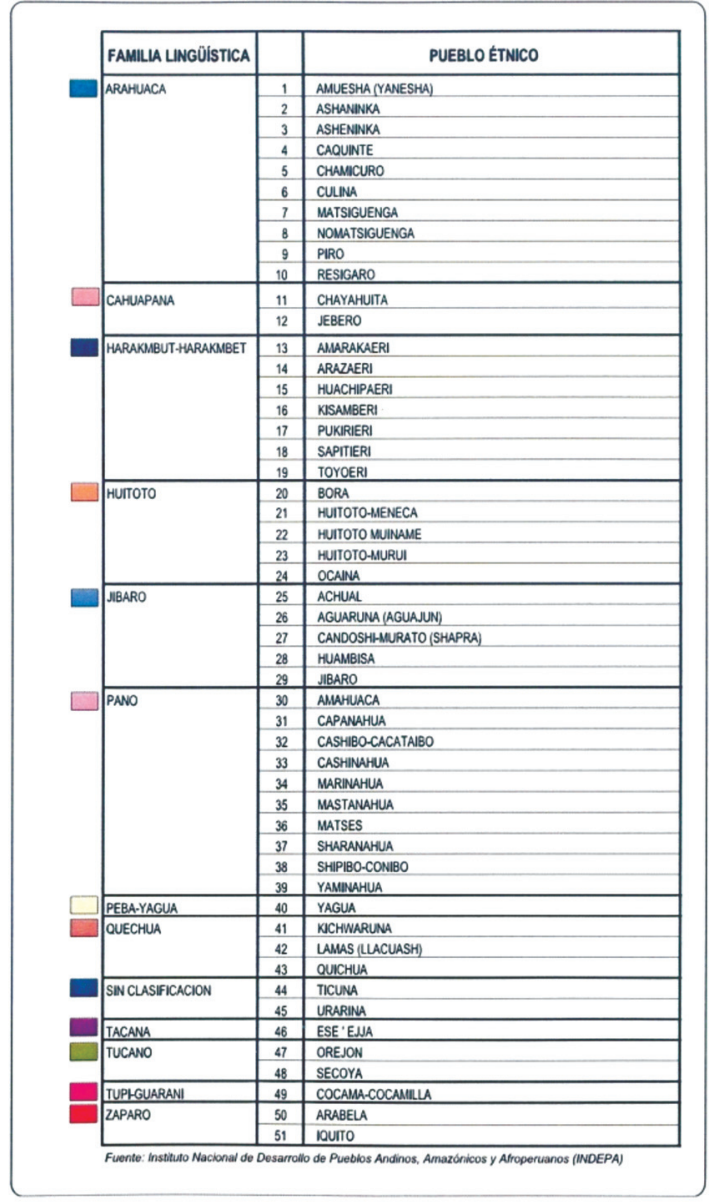

The script used during interviews included questions such as: What is the difference in getting attention by a midwife or by a health center? If the birth was in the home: Why did you not go to the health center for care? What kind of care did you receive during delivery and postpartum? What position did you take to give birth? What do you usually drink; eat, among other things, when pregnant? What is the difference between a homebirth versus at the health center? What are the main reasons why pregnant women do not seek the health services?

Data were analyzed based on reading and rereading of interviews, supplemented with participant observation and articulated by theoretical knowledge. The study sought to give visibility to the cultural knowledge of the Kukama Kukamiria.

\section{RESULTS AND DISCUSSION}

Based on the description and analysis of the empirical data, the following themes emerged concerning the discourses among the Kukamas kukamirias community: the organization of birth 
care, the destination of the placenta, and postpartum care.

\section{Traditional antenatal care}

Within the worldview of the Kukama kukamiria culture, the singing of birds is a sign that the woman is pregnant, for example. The signs and early symptoms of pregnancy are very connected with the natural environment, and are considered to be special events ${ }^{6,13}$. Complementing this "magical" knowledge, the Kukama kukamiria woman also recognizes pregnancy as an occurrence that follows the absence of menstruation.

Pregnancy is an important event not only for the family structure, but also for the midwife, as well as the community as a whole. In this context, the midwife is present from the first moment of life, providing care and guidance for the mother and infant in avoiding risks, kutipa, which can harm the health of both mother and child. Kutipa is a term used to name all events that are related to unhealthy aspects of everyday life, described as an impurity that enters the body or the soul. The being "kutipada" is related to disease - physical, emotional, or spiritual.

The kutipa can be referred to the action of evil spirits, as well as to the consequences arising from birth itself or, to the assistance given once a woman suffers from interventions during labor at the health service such as: vaginal wounds resulting from episiotomy, pain resulting from oxytocin augmentation, hematomas resulting from Kristeller (fundal pressure), among others. Moreover, issues related to evil spirits, can also occur among the health care providers, depicted by the cold and insensitive treatment of a pregnant woman.

During pregnancy, restrictions and diets are common occurrences among many indigenous communities ${ }^{14}$. Generally cassava flour, banana, fish and other specific types of meat from animals of the forest are consumed.

"Here, when you're like this [pregnant] you follow diet of various things, like watermelon: you do not eat because it causes kutipa, because it leaves too big the head of Ilullo [infant]; do not eat, do not drink "caña" [sugarcane, sugarcane juice] because they say it gives too much blood like hemorrhage, do not eat acidic things, such as cider, because the blood produces water and then you swell [edema]; the paca (a mammal found in Peru) also is not eaten, because it leaves the llullos [infants] whiners." (Karen, pregnant, 41 years old)

Between the fourth and sixth month of pregnancy, Kukama kukamiria women seek a midwife to carry out the "sobada" which are therapeutic massages. The "sobada" is often performed during prenatal care, a significant indication that the care and attention begins well before birth.

Pregnant women continue executing tasks, such as: going to the farm, cooking, caring for the small animals, washing clothes, doing crafts and all the chores concerning the care of the house considered important exercises that help in preparing the body for childbirth. Among the Kukama kukamiria, there exists the idea of balance: neither inertia, nor the excess of tasks.

A very important caring concept within the Kukama kukamiria tradition is the relationship between hot and cold. It is custom to boil plant leaves during bathing, to "ligar" or "fazer ligadura", to rid all cold temperatures from the pregnant woman's body and prepare it for delivery.

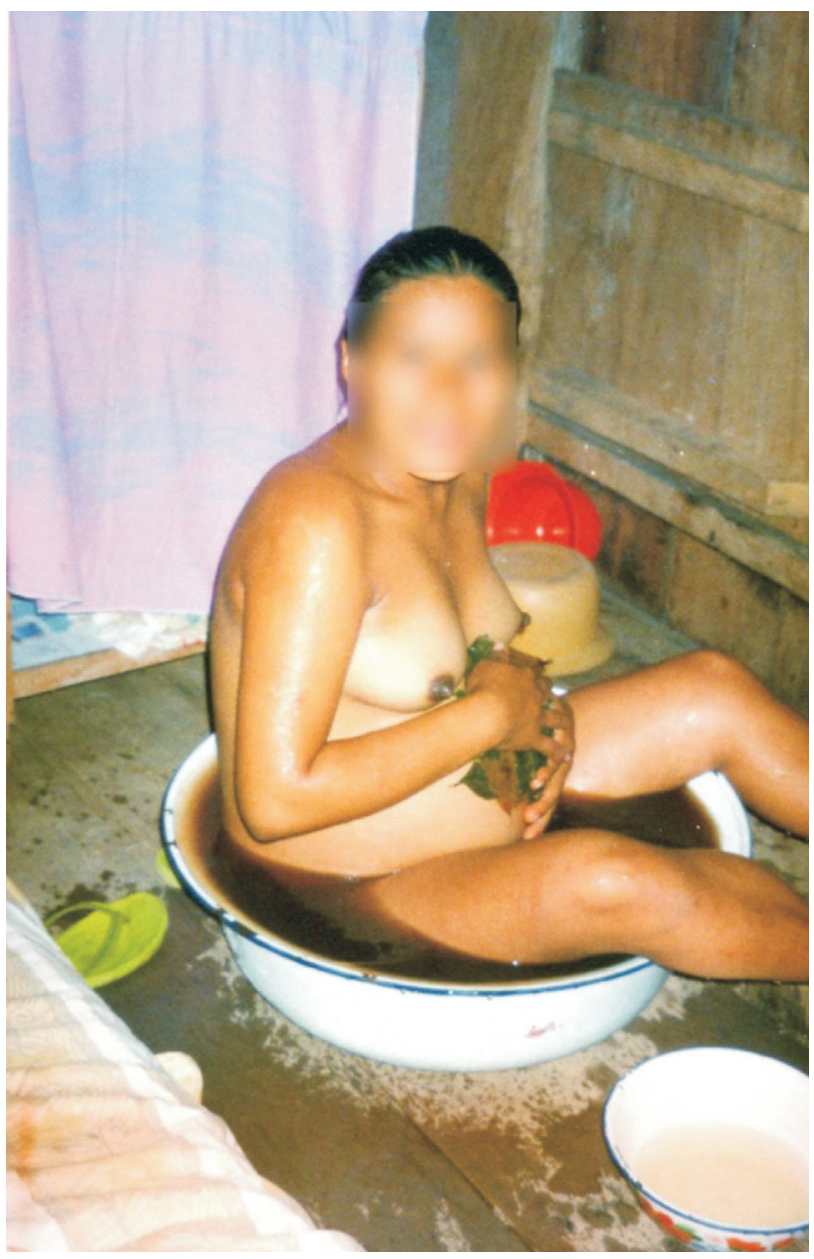

Figure 1: Hot bath known as "ligadura"

"You must "ligar" due to the cold, because sometimes we have a cold, and the cold also hurts our belly and so it alerts us. The plants that are used are the mallow leaves, sapucho [ripe banana], verbena- lemon, citron. It is placed in boiling water and then into the bowl when it's warm, and then you can stay sitted or standing, with legs open for the warmth to climb up, and then you will know if it is cold, for a cold sweat will run down your legs." (Marcela pregnant 25 years old)

\section{Traditional care in labor and childbirth}

When labor starts, the mother continues doing her housework until the pain becomes more intense. Women usually consume a hot drink to 
hurry the contractions. The cotton leaf teas, white albaca, oregano, mauve, sharamasho, among others, guarantee a fast delivery, with less pain and complications.

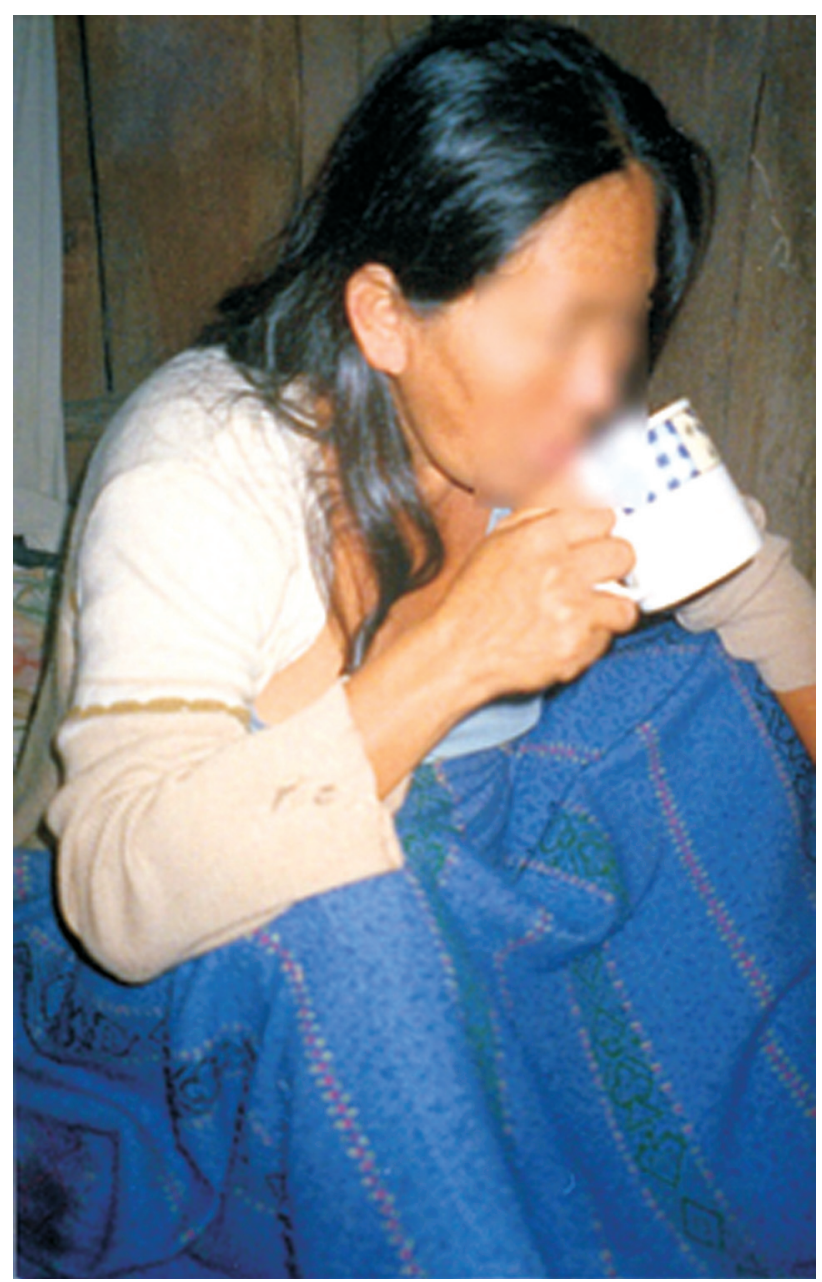

Figure 2: Pregnant woman in labor drinking tea

The midwife observes and controls the woman's head sweat, pulse intensity, and knows from experience, that once labor has started there is a determined time for the child to be born. She does not perform a vaginal examination, but verifies the infant's movements at each contraction; also knowing the differences between when the child may be in fetal distress, (weak movements) or when it is without complications (good and continuous contractions). The environment for the delivery and postpartum care should be a closed space, with dull lighting and no noise so that the infant can be born fast and in a calmer ambiance; however, she is also accompanied by her husband, family member, and midwife.

The preferred positions for birthing vary greatly: sitting, semi-lying down, standing, kneeling, or squatting. During the study, no woman interviewed made reference to giving birth lying down. Studies have shown the benefits of adopting a vertical position during labor and delivery ${ }^{15}$. When

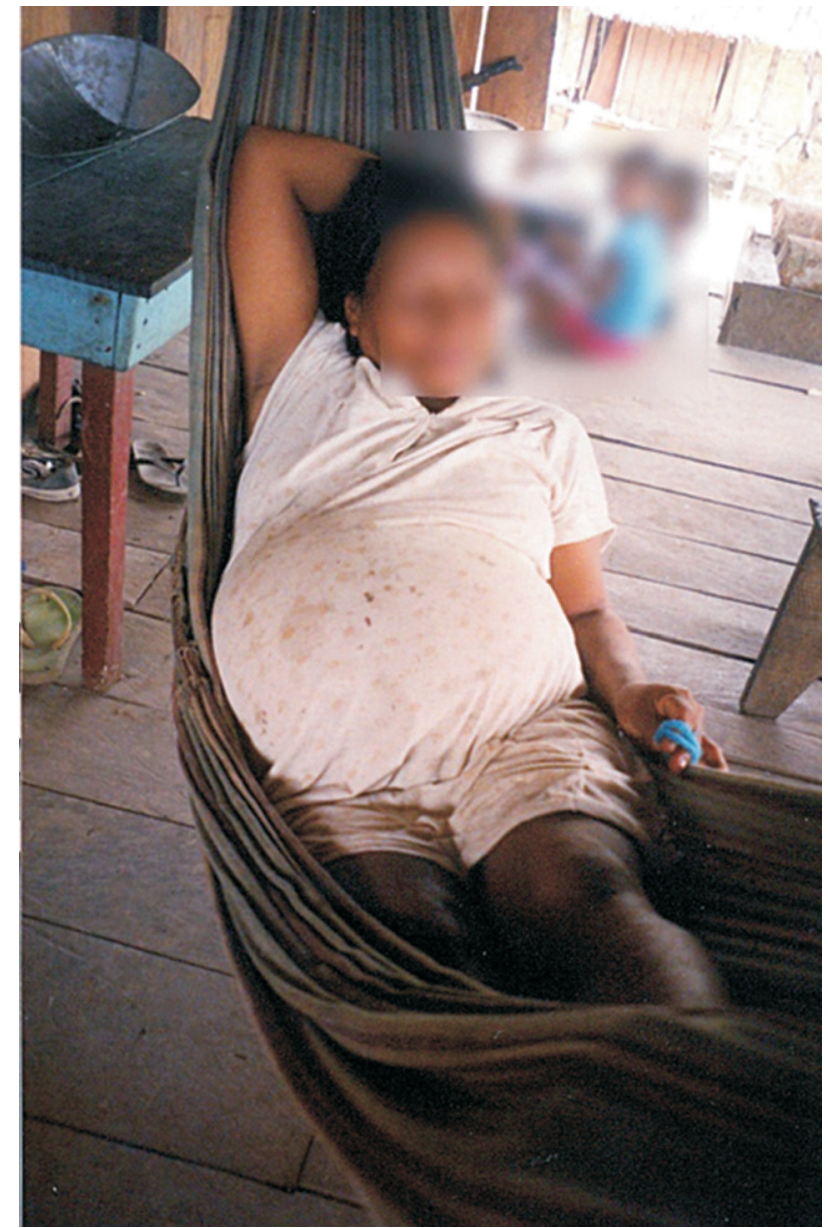

Figure 3: Home is where women prefer to have their child

it is a norm for women to choose a birthing position, a preference is given to vertical positioning ${ }^{14}$.

When the infant is born, the midwife does not cut the umbilical cord immediately. It is custom to expect the delivery of the placenta as a continuation of childbirth. Hence the midwife waits to cut the navel allowing more oxygen for the infant ${ }^{16}$.

After birth, the midwife continues postpartum care, making sure that the expelled placenta follows its correct destination. This movement has a lot of meaning in the Kukama kukamiria culture, and it is directly related to the future of the infant within the family and social environment.

\section{The Health Center}

The Kukamas kukamiria population until the mid-1990s, sought solely the help of the health service in cases considered high risk. The help of the health service represents a last resort due to experiences of hostile treatment by the healthcare providers ${ }^{17}$.

Prenatal care in the health service consists of vital function control, measuring of the fundal height, and listening to the fetal heartbeat6,14. In some circumstances, none of these presumed measurements were taken: either due to lack of 
equipment (tensiometer, measuring tape, stethoscope); or due to unwillingness on the part of the healthcare provider.

Thus, it is evident that there is a distance between the attention provided by the traditional model, as is the case among midwives within the San Regis community, and the bio-medical model, which begins to be disseminated through the implementation of health policies.

The panorama described, reveals that health care providers do not have a general awareness and understanding of interculturalism ${ }^{18}$, a more comprehensive treatment of indigenous peoples, their values, and respect; or recognition for their traditional thought. There is also a general lack of knowledge regarding the benefits that dialogue can provide among differing players within the system of care ${ }^{10,19,20}$.

The process of childbirth care within health services follow specific procedures such as: the use of obstetric instruments, frequent vaginal exams, isolation, "cold showers" before and after delivery, the administration of oxytocin, episiotomy, the pressure on the uterus (Kristeller maneuver), among others. These methods are unknown to most women and are frequently rejected, for they are considered to be unnecessary and invasive.

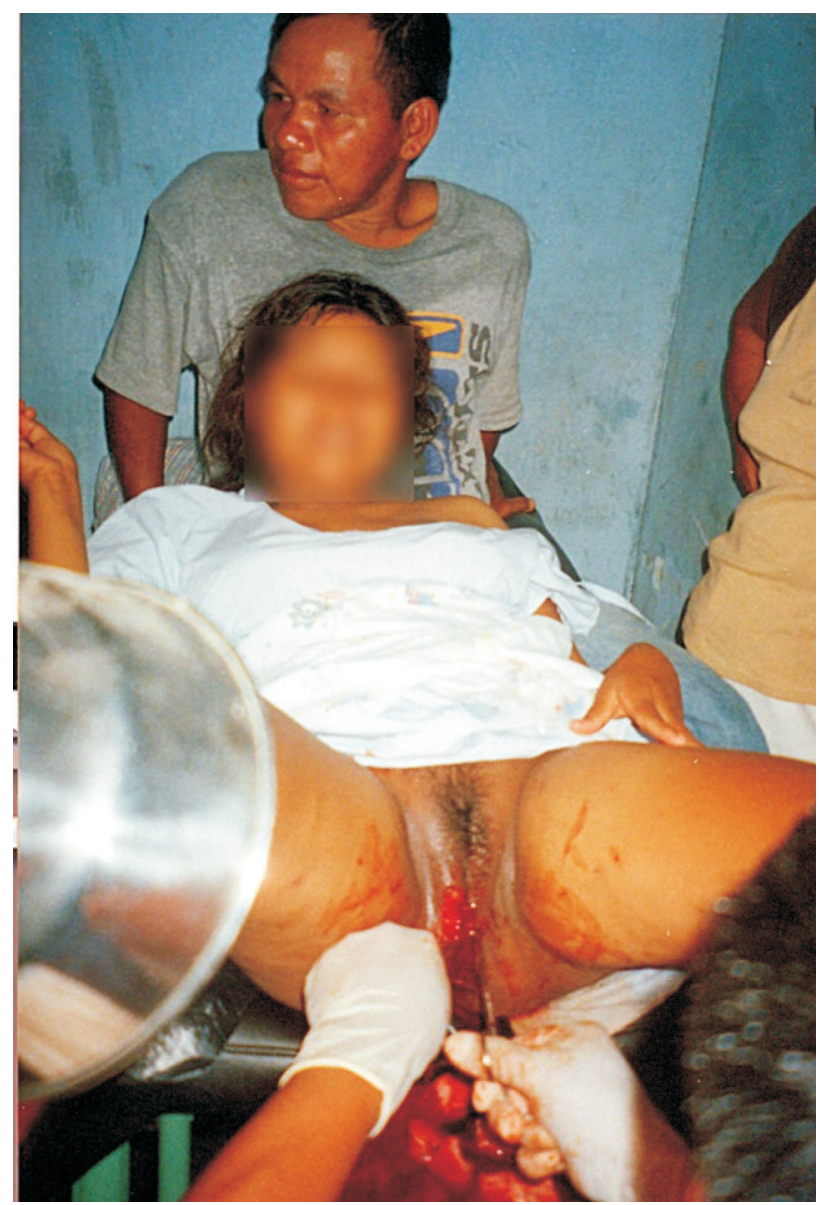

Figure 4: Birth at the health service and the unnecessary practives experienced by its patients
Studies show that when the expert knowledge of the official public health system ignores cultural diversity, there is a consistent resistance by the indigenous mothers in the use of the health services ${ }^{18,21}$.

This context makes women feel uncomfortable with the option of giving birth at the health center. There is a lack of preparation from the health care providers in understanding the ways of life and care in the community. The impossibility of performing rituals associated with care for the placenta and the restriction of traditional tea use in labor and postpartum care, are perceived as threats to women and newborn 's health and wellbeing. The abandonment of the women during labor, a time considered to be highly vulnerable, physically and spiritually, is perceived as not only inappropriate and detrimental, but as potentially causing bad luck that can arise from the lack of symbolic mechanisms of protection ${ }^{19}$.

The difference in worldview between the healthcare provider and the health service user becomes a pre-determined cultural barrier, which limits the access of services to the latter ${ }^{22}$. A sense of frustration is frequently expressed by the population of San Regis when faced by the treatment provided by the health facilities.

"In my house, if I am to give birth, I'll go get my midwife. It is normal to not want to go to the health service [laughs], there, the nurse is very angry. There is a lady who went to have her son around my age. She is from another community and said she was afraid, and the nurse kept saying: 'who told you to want a son, already at such old age? When we are old we should no longer want to have children'". (Karen pregnant 41 years old)

Many procedures that are considered by the health care providers to be beneficial may be considered harmful and traumatic, as described by Teresa:

"I decided to give birth at the health center, where the nursing technician made the cut [episiotomy] with a razor." (Teresa pregnant 29 years old)

The cold (from the environment) and the coolness (from the treatment by health care providers) so feared and avoided within their culture, are perceived both by the looks given from the healthcare providers, as well as felt on the skin; experiencing the cold shower one is expected to take so as to be "clean" and prepared for delivery.

The invisibility of such violence has been unveiled by the lack of sensitivity from the health care providers to interact with the mothers, furthermore this violence is enhanced by the increased physical, emotional and social vulnerability experienced during the process of labor and birth. When added to the physical vulnerability, other stressors, such as social and economic factors, as well as belonging to an ethnic group that stands 
as a minority in Peru, become heightened. This summation of events has resulted in a confidence crisis within the relationship between doctor and patient ${ }^{18}$.

\section{Buried on sacred ground, or in the garbage: placenta and postpartum care at home versus within the health system}

The placenta has a symbolic representation within the Kukama kukamiria universe that organizes its community and gives meaning to their existence.

The placenta has a sacred meaning. Based on Geertz ${ }^{23}$ :

\begin{abstract}
"(...) the sacred symbols relate an ontology and a cosmology to an aesthetics and a morality: their peculiar power comes from its purported ability to identify fact with value at the most fundamental level, to give a comprehensive normative meaning to what, otherwise, would just be real" (p. 144)
\end{abstract}

After birth, is important to insure the right destination and treatment for the placenta because it is considered to be a "life that gave life to another being" (Dolores, 25 years old). There is an understanding that without the placenta, there would be no new life, hence it is a constituent part of this being, its family and, by extension, of the Kukama kukamiria people. Therefore, for them, it is not a waste product to be disposed postpartum.

Within the life history of families, not only among Amazonian indigenous people, but also in the Andean region of Peru ${ }^{24}$, the placenta must be buried by the father of the child, in the garden of the house. The placenta burial symbolizes and signifies protection and strength for the new member and its mother.

Among Kukama kukamiria and other cultures ${ }^{14,24}$ the relationship between newborn and placenta is very important, existing an association between newborn, placenta and mother, where the three remain united during the nine months of pregnancy, bridging communication and maternalfetal exchange.

In the health service, the placenta is considered to be a bodily waste, treated similarly to cysts, blood, pus or any used bandages: as disposal; many times being discarded at random and ingested by dogs, rats and other animals. This fact alone shows the lack of adequate infrastructure for birth care. Within this context, routine health procedures are organized with a focus on interventions ${ }^{25}$, at the expense of the people, and the conduct of health care providers - in treating these dimensions as irrelevant - scare women who seek assistance in delivery.

Based on Kukama kukamiria culture, after birth the cultural aspects of care are marked by a period of immunological defense, with the implementation of diets and quarantines which aims to prevent illness.
Women tie a scarf around their heads to prevent the entry of any form of air. The mother is kept well guarded, fed and at rest along with her newborn. Such care is considered very important since the woman finds herself "open" and "offended" (referring specifically to the state of the "open" uterus, commonly called, "the home of the newborn").

A comparative description between the two modes of care for birth is important in examining how these factors are depicted and present in the daily lives of the San Regis women. Nevertheless, depending on the evolution of the mother and their child at the health center, they may be discharged within 24 hours.

Regardless of circumstance, the mother receives antibiotics and anti-inflammatory (megacilin intramuscularly, and ibuprofen orally) which they dislike because they understand that these drugs negatively influence breastfeeding (in their words, "contaminate the milk"); leading them to the idea that these medications can "kill" the child's defenseless body.

At the health institution, women are forced to bathe, feeling mistreated and disrespected. Some health care providers see such "resistance to bathe" as a sign of incivility.

"In the health service they do not care for you, to
them it is the same if you get cold water, for them
once a mother gives birth, she should get a bath
with cold water, this is bad for the woman's health
that needs taking care of. Same with the Ilullo
[infant] who cannot bathe in the first days of life
because it is small and loses heat. So in the health
service they should change these habits." (Laura,
Postpartum, 43 years old)

Furthermore, the Pan American Health Organization (PAHO) states that interculturality relates to the relationship and interaction between differing cultures. Interculturality is based on dialogue towards respecting particularities and individuals, for it is not based on imposition or oppression, but in having solidarity for one another and seeking equity of care ${ }^{25}$.

Health services are offered as an opportunity to meet different needs ${ }^{10}$, diseases, as well as prenatal care, childbirth and consequently birth complications. Once mothers feel disrespected through the scorn of their customs, the community can start to interpret the health system as a place that puts their health at risk.

This study revealed that knowledge carved out by the cultural history and customs of the Kukamas kukamirias, is not considered by the organization of care delivery services. Their knowledge is despised and excluded, being considered "below standard", primitive and inadequate. When women seek health services at birth, they feel disrespected by the system's imposed concepts of the birthing experience. 
It is necessary to recognize that this "prior" knowledge is a part of the setting in which, for this population, life acquires meaning and a sense of belonging. And for that recognition to occur, it is necessary to rethink the established health service protocols ${ }^{24}$.

In order to understand the richness of this "other knowledge", different approaches and ways of handling care, that are perceived as effective and satisfactory, are important not only in seeking inclusion but also in finding strategies that facilitate dialogue. This could lead to better communication between actors and a more effective intercultural relationship.

The concept of support, has been highlighted by other studies ${ }^{26}$, to be a key factor in eliciting a positive response by the 'other' in this system of care; in turn, the 'other's demands become more effective and in turn, a guide for better implementation of proposed interventions ${ }^{27}$.

Women are not willing to leave their customs behind to face "threatening" conditions in the health center. The presence of a midwife remains very important towards mutual understanding, trust, kindness, cultural awareness and the quality of care provided.

\section{REFERENCES}

1. Ministerio de salud. Prevención en salud: Salud de los pueblos indígenas. [acceso em 26/08/ 2013] disponível em: www.minsa.gob.pe/ index.asp?.op $=6$

2. Ministerio de Salud - Oficina General de Estadística e Informática. [Acesso em 06/07/ 2013] Disponível em http://www.minsa. gob.pe/ portada/estadistica.asp

3. INEI.Mortalidad Infantil y Fecundidad [acceso em 26/08/2013]. Disponível em: http://www. inei.gob.pe/biblioineipub/bancopub/Est/ Lib0001/capit003.htm

4. Censo 2007. [acesso em 26/08/2013]. Disponível em http://censos.inei.gob.pe/Censos $2007 /$ Documentos/Exposicion _ Comunidades_Indigenas2007.pdf

5. Plan General de la Estrategia Sanitaria Nacional Salud de los Pueblos Indígenas 2009 2012. [acceso em 26/08/2013] disponível em: http://www.ins.gob.pe/repositorioaps/0/7/jer/ censi_plan_ma/Plan\%20General \%20de\% 20ls\%20Estrategia\%202010-2012. pdf p.11,21.

6. Yajahuanca RSA. Sem Kutipa: concepções sobre saúde reprodutiva e sexualidade entre os descendentes Kukamas kukamirias, Peru. [dissertação]. São Paulo: Faculdade de Saúde Pública da Universidade de São Paulo, 2009, 8085p.

7. Enkim. M; Kierse, M.; Nielson, J.; Crowter, C.; Duley, L.; Hodnett, E.; Hofmeyr, J. Guia de Atenção Efetiva na Gravidez e no Parto. $3^{a}$ edi-
Finally, in the case of San Regis, health care providers have shown a lack of consideration regarding the indigenous culture Kukama kukamiria. It is important that the promotion of health technologies in childbirth also intersects with the traditional knowledge of the people it seeks to serve.

A preference by the Kukama Kukamiria women for traditional care is justified based on perceptions of neglect and vulnerability at institutionalized health centers, resulting from the lack of consideration by the health services for the cultural and well-being specificities of the pregnant women.

A partnership between these two methods and worldviews would benefit the population in gaining the best care both of these actors can provide, individually and together for the improvement of maternal and child health among the Kukama kukamiria women in Peru, as well as within other indigenous communities around the world.

\section{ACKNOWLEDGEMENTS}

Thanks to the Ford Foundation (process No 15056762) for financial support during the author's graduate studies at the University of Sao Paulo's School of Public Health - USP.

ção. Rio de Janeiro: Guanabara Koogan, 2007; p. 279.

8. Diniz SG. Gênero, saúde materna e o paradoxo perinatal. Rev. Bras. Crescimento Desenvolv. Hum. 2009; 19: 313-26.

9. Mathez-Stiefel SL, Vandebroek I, Rist S. Can Andean medicine coexist with biomedical healthcare? A comparison of two rural communities in Peru and Bolivia. J Ethnobiol Ethnomed. 2012 Jul 24;8:26. DOI: 10.1186/ 1746-4269-8-26.

10. Atrash HK, Carpentier R. The evolving role of public health in the delivery of health care. J. Hum. Growth Dev. 2012; 22(3): 396-399

11. Gobierno Regional de Loreto. Análisis de la Situación de Salud de la Región Loreto-2010. Dirección Regional de Salud de Loreto [acesso em: 25 abr. 2013]. Disponível em: www.bvsde. paho.org/documentosdigitales/bvsde/texcom/ ASIS-regiones/Loreto/Loreto2010.pdf. P.14

12. Haguette, TMF. Metodologias qualitativas na Sociologia. Petrópolis: Vozes; 1992. p. 66-91.

13. Azevedo, Marcos Augusto P. de and Adorno, Rubens de Camargo Ferreira. Juventude e Reprodução entre os Guarani-Mbyá da Aldeia Morro da Saudade na Periferia da Cidade de São Paulo. Rev. bras. crescimento desenvolv. hum. [online]. 2007, vol.17, n.2, pp. 64-73. ISSN 0104-1282.

14. Medina AI; Mayca JP. Creencias y costumbres relacionadas con el embarazo, parto y puerperio en comunidades nativas Awajun y Wampis. Rev. Perú. Med. Exp. Salud Pública. 2006; 23 (1): p.22-32. ISSN 1726-4634. 
15. Paciornick, M. Aprenda a nascer como os índios: Parto de cócoras. São Paulo: Brasiliense; 1997. p. 46.

16. McDonald SJ, Middleton P, Dowswell T, Morris PS. Effect of timing of umbilical cord clamping of term infants on maternal and neonatal outcomes. Cochrane Database Syst Rev. 2013 Jul $11 ; 7$. DOI: 10.1002/ 14651858.CD004074.pub2.

17. Gil LP. Políticas de Saúde, Pluralidade Terapêutica e Identidade na Amazônia. Saúde Soc. 2007; 16: p.48-60. ISSN 0104-1290. http:// d x.doi . org/10.1590/S010412902007000200006.

18. Respectful Maternity Care Advisory Council, White Ribbon Alliance for Safe Motherhood. (2011). Respectful maternity care: the universal rights of childbearing women. Washington, DC: WRA. Retrieved [August 8th, 2013] p.1-6.

19. Anderson J. Mortalidad Materna y derechos humanos. Centro de Investigación de la Universidad del Pacífico. 2011; 38(69): 101127/ISSN 0252-1865 Copyright 2011.

20. Silva, Ana Verônica R. and Siqueira, Arnaldo A. F. de. O valor do suporte à parturiente: um estudo da relação interpessoal no contexto de um Centro de Parto Normal. Rev. bras. crescimento desenvolv. hum. [online]. 2007, vol.17, n.1, pp. 126-135. ISSN 0104-1282.
21. Knipper, Michael. Beyond the indigenous: health and interculturality at the global level. Rev Peru Med Exp Salud Publica [online]. 2010, vol.27, n.1 [cited 2013-07-26], pp. 94-101. http:// d x.do i . org/10.1590/S172646342010000100014.

22. Macedo MDC; Barros DD. Saúde e serviços assistenciais na experiência de jovens Guarani da comunidade de Boa Vista. Rev. Ter. Ocup. 2010, 21(3): 182-188. DOI: http://dx.doi.org/ 10.11606\%2Fissn.2238-6149.v21i3p182-188.

23. Geertz C. A interpretação das culturas. LTC: RJ; 1989.p.143-144

24. Davidson JR. La sombra de la vida: La placenta en el mundo andino. Bulletin IFEA. 1983; 12(3/4): 69-81.

25. Lévi-Strauss C. A eficácia simbólica. In: Antropologia Estrutural. São Paulo: Cosac Naif; 2008.

26. Dittz ES; Mota JAC; Sena RR. O cotidiano no alojamento materno, das mães de crianças internadas em uma unidade de Terapia Intensiva Neonatal. Rev. Bras. Saúde Matern. Infant. 2008; 8(1): 75-81. ISSN 1519-3829.

27. Silva Junior AG; Merhy EE; Carvalho LC. Refletindo sobre o ato de cuidar da saúde. In: Pinheiro R; Mattos RA. (Orgs.). Construção da integralidade: cotidiano, saberes e práticas em saúde. Rio de Janeiro: Abrasco; 2003.p.10. http://dx.doi.org/10.1590/S0102-311X 2004000500037 